\title{
UTILIZAÇÃO DA MICROTÉCNICA PARA A IDENTIFICAÇÃO SOROLÓGICA INTRATÍPICA DE ESTIRPES DE POLIOVIRUS DOS TIPOS $1 \mathrm{E} 3$
}

STEWIEN, K. E. \& LACERdA, J. P. G. de Utilização da microtécnica para a identificação sorológica intratípica de estirpes de poliovírus dos tipos 1 e 3 . Rev. Saúde públ., S. Paulo, 11:135-42, 1977

Resumo: Foram estudadas de modo comparativo a macro e a microtécnica em provas de identificação sorológica intratípica de 28 estirpes de poliovirus dos tipos 1 e 3 , segundo o método da "comparação dos indices de neutralizacão". Os resultados alcancados mostraram uma correlação elevada entre os indices de neutralizacão obtidos com ambas as técnicas empregadas - 0,931 e 0,971 após incubaçāo de três e cinco dias, respectivamente - e correspondência total na identificação das estirpes examinadas. Conclui-se que a microtécnica pode ser utilizada em substituiçâo da macrotécnica tradicional na identificação intratípica de poliovirus dos tipos 1 e 3 , com a vantagem da economia de meios e reagentes, e até mesmo com sensivel redução de esforços humanos e tempo de execucão das provas.

UNITERmos: Poliovírus. Marcadores genéticos. Microtécnica.

\section{N T R O D U C $\AA$ O}

A microtécnica tem recebido, desde a sua introdução por Takatsy e col. ${ }^{16}$ (1954), crescente aceitação nos laboratórios de Virologia. Modificada por Sever (1962), a referida técnica vem sendo empregada há vários anos em numerosos laboratórios nas reações de fixação de complemento (FC'), hemaglutinação e inibição da hemaglutinação (IH), e inibição metabólica ${ }^{9}{ }^{10}$. Em 1963, foi possível a Rosenbaum e col. ${ }^{7}$ utilizá-la pela primeira vez na reação de soro-neutralização. Posteriormente, os referidos pesquisadores introduziram nesta reação de microneu- tralização diversos aperfeiçoamentos que possibilitaram a sua utilização, tanto na dosagem de anticorpos contra diversos vírus, quanto na títulação e identificação destes mesmos vírus $1,2,3,4,5,8,9,11$, 14, 15, 17

Antes do advento da microtécnica, a execução das provas de dosagem de anticorpos e de identificação de vírus era relativamente complexa, demorada e, sobretudo, dispendiosa. A realização de considerável número destas provas era tarefa de apenas alguns laboratórios bem equipados e com amplos recursos. Com a introdu-

- Do Departamento de Microbiologia e Imunologia do Instituto de Ciências Biomédicas da USP - Av. Dr. Arnaldo, 715 - São Paulo, SP - Brasil.

* Da Secão de Virus Respiratórios e Enterovirus do Instituto Adolfo Lutz - Av. Dr. Arnal. do, 355 - São Paulo, SP - Brasil. 
STEWIEN, K. E. \& LACERDA, J. P. G. de - Utilização da microtécnica para a identificação sorológica intratípica de estirpes de poliovirus dos tipos 1 e 3. Rev. Saúde públ., S. Paulo, $11: 135.42,1977$.

ção da microtécnica, foi dada a possibilidade aos demais laboratórios de Virologia desempenhar aquela tarefa, em virtude das vantagens que ela oferece em relação à macrotécnica tradicional.

Em primeiro lugar, verifica-se uma economia de meios e reagentes, tais como, antígenos virais, anti-soros específicos, culturas de células e meios de cultura, da ordem de 10 vezes. Em segundo lugar, reduz-se sensivelmente os esforços humanos e o tempo de execução das provas. Em conseqüência, são reduzidos extraordinariamente os custos totais das reações, chegando no caso da dosagem de anticorpos neutralizantes a ser de mais de 30 vezes. Neste cálculo ainda não se inclui a economia de gastos com a lavagem, desinfecção e preparação dos diversos materiais de laboratório necessários às reações.

Mostrando-se a microtécnica útil e muito vantajosa em numerosos laboratórios de virologia, inclusive em nosso próprio, propusemo-nos, com o presente trabalho, adaptá-la à identificação sorológica intratípica de poliovírus, procurando com isto estender as suas vantagens para tal propósito.

\section{MATERIAL E METODOS}

Equipamento - $\mathrm{O}$ equipamento de microtitulação foi fornecido pela Firma Cooke Engineering Co., Alexandria, Va., EUA. Utilizaram-se para o propósito deste trabalho: 1. Microplacas de poliestireno rígido para culturas de células, apresentando 96 cavidades de fundo plano. As microplacas puderam ser utilizadas diversas vezes, quando lavadas com Extran, Merck. 2. Pipetas conta-gotas de polipropileno autoclavável, com capacidade total de 6 mililitros, apresentando adaptador para sucção oral e ponta de aço inoxidável, calibrada para a distribuição de gotas de 25 ou 50 microlitros. 3. Incubadora portátil para a incubação das culturas em microplaca num ambiente úmido e com 4 a $5 \%$ de gás carbônico.
Culturas de células - Foram utilizadas culturas de células da linhagem Hep-2, como alternativa das culturas primárias de rim de macaco rhesus (RMK), reconhecidamente mais dispendiosas ${ }^{13}$. As células Hep-2 eram cultivadas em meio de crescimento de Eagle MEM, a base da solução balanceada de Earle, contendo $10 \%$ de soro fetal bovino (Flow Laboratories, Rockville, Ma., EUA), 200 unidades de penicilina e 200 microgramas de estreptomicina por mililitro de meio. $O$ meio de manutenção continha $2 \%$ de soro fetal bovino. Para a realização das provas, eram preparadas culturas em tubos (macrotécnica) e nas cavidades das microplacas (microtécnica). Os tubos recebiam inóculos de $1 \mathrm{ml}$ de suspensões contendo cerca de 100.000 células por mililitro e as cavidades, inóculos de $0,025 \mathrm{ml}$ de suspensões contendo em torno de 400.000 células por mililitro. Quando as culturas mostravam camada celular confluente, o que ocorria após 2 a 3 dias de incubaçāo, o meio de crescimento era substituído por meio de manutenção.

Virus - Foram utilizadas como estirpes de referência nas provas de identificação intratípica dos poliovírus do tipo 1 e do tipo 3 , respectivamente os protótipos Mahoney e Saukett $\mathrm{e}$ as estirpes atenuadas de Sabin LSc2ab e Leon 12a b. Foram examinadas 18 estirpes de poliovírus do tipo 1 e 10 estirpes do tipo 3, isolados de casos de paralisia no Instituto Adolfo Lutz ${ }^{13}$.

Soros imunes - Os soros anti-Sabin I e anti-Sabin 3 foram preparados em coelhos, segundo método anteriormente descrito ${ }^{13}$. Os títulos dos referidos soros hiperimunes eram 1:640 e 1:1.280, e foram utilizados nas diluições de $1: 300$ e $1: 600$, respectivamente, na execução das provas de identificação intratípica.

Provas de identificação intratípica - 0 método utilizado foi o da comparação dos indices de neutralização, descrito anteriormente em detalhe ${ }^{12}$. As diluições dos vírus e as misturas vírus-soro imune fo- 
STEWIEN, K. E. \& LACERDA, J. P. G. de - Utilização da microtécnica para a identificaçāo sorológica intratípica de estirpes de poliovírus dos tipos 1 e 3. Rev. Saúde públ., S. Paulo, 11:135.42, 1977.

ram preparadas em tubos esterilizados e, após um período de incubação de $5 \mathrm{~min}$. (cronometrados), distribuídas nas culturas de células Hep-2. Cada diluição de vírus e cada mistura de vírus-soro era inoculada em 4 tubos de cultura e em 4 cavidades de microplaca, recebendo os tubos volumes de $0,2 \mathrm{ml}$ e as cavidades. $0,1 \mathrm{ml}$. As culturas inoculadas eram então submetidas à incubação a $36-37^{\circ} \mathrm{C}$. Leituras eram realizadas após 72 horas e 120 horas de incubação e os títulos calculados segundo método de Reed \& Muench (1938). Para a identificação intratípica das estirpes, adotou-se o critério de Plotkin, Cohen e Koprowski (1961) ${ }^{6}$.

\section{RESULTAUOS E DISCUSSAO}

Os resultados das provas de identificação intratípica obtidos com a macro e a microtécnica são apresentados nas Tabelas 1 e 2, respectivamente para as estirpes de poliovírus dos tipos 1 e 3 . Verifica-se que os índices de neutralização (IN) das estirpes de referência do tipo 1 (Makoney e LSc2ab) e do tipo 3 (Saukett e Leon $\left.12 a_{1} b\right)$ apresentaram valores iguais ou ligeiramente diferentes entre si em ambas as técnicas utilizadas, sendo a diferença entre os indices das estirpes naturais e atenuadas praticamente igual nas provas realizadas.

Conforme o critério de identificaçāo adotado, as estirpes de poliovírus do tipo 1 que apresentaram, após um período de incubação de 72 horas:

\section{Macrotécnica}

a) IN $\geqslant 3,16-1 / 3(3,16-0,84)=$ $=2,39 \rightarrow$ estirpe isóloga a vacinal $(-)$;

b) IN $\leqslant 3,16-2 / 3(3,16-0,84)=$ $=1,62 \rightarrow$ estirpe heteróloga a vacinal $(+)$;

c) $2,39>$ IN $>1,62 \rightarrow$ intermediária $( \pm)$.

\section{Microtécnica}

a) IN $\geqslant 3,00-1 / 3(3,00-0,66)=$ $=2,22 \rightarrow$ estirpe isóloga a vacinal $(-)$;

b) IN $\leqslant 3,00-2 / 3(3,00-0,66)=$ $=1,44 \rightarrow$ estirpe heteróloga a vacinal $(+)$;

c) $2,22>$ IN $>1,44 \rightarrow$ intermediária $( \pm)$

Da mesma forma, após um período de incubação de 120 horas, as estirpes do tipo 1 que apresentaram em ambas as técnicas:

a) IN $\geqslant 2,22 \rightarrow$ estirpe isóloga $(-)$;

b) IN $\leqslant 1,44 \rightarrow$ estirpe heteróloga $(+)$

c) $2,22>$ IN $>1.44 \rightarrow$ intermediária $( \pm)$.

Segundo o mesmo critério de identificação, as estirpes do tipo 3 que apresentaram, após 72 horas de incubação:

1. Macrotécnica

IN $\geqslant 2,89 \rightarrow$ estirpe isóloga ( - );

IN $\leqslant 2,11 \rightarrow$ estirpe heteróloga

$(+)$;

$2,89>\mathrm{IN}>2.11 \rightarrow$ intermediária $( \pm)$.

2. Microtécnica

IN $\geqslant 3,11 \rightarrow$ estirpe isóloga $(-)$;

IN $\leqslant 2,38 \rightarrow$ estirpe heteróloga $(+)$;

$3,11>$ IN $>2.38 \rightarrow$ intermediária $( \pm)$

Da mesma forma, após um periodo de incubação de 120 horas, as estirpes que apresentaram :

\section{Macrotécnica}

IN $\geqslant 2,94 \rightarrow$ estirpe isóloga ( - );

IN $\leqslant 2,22 \rightarrow$ estirpe heteróloga $(+)$;

$2,94>$ IN $>2.22 \rightarrow$ intermediária $( \pm)$. 


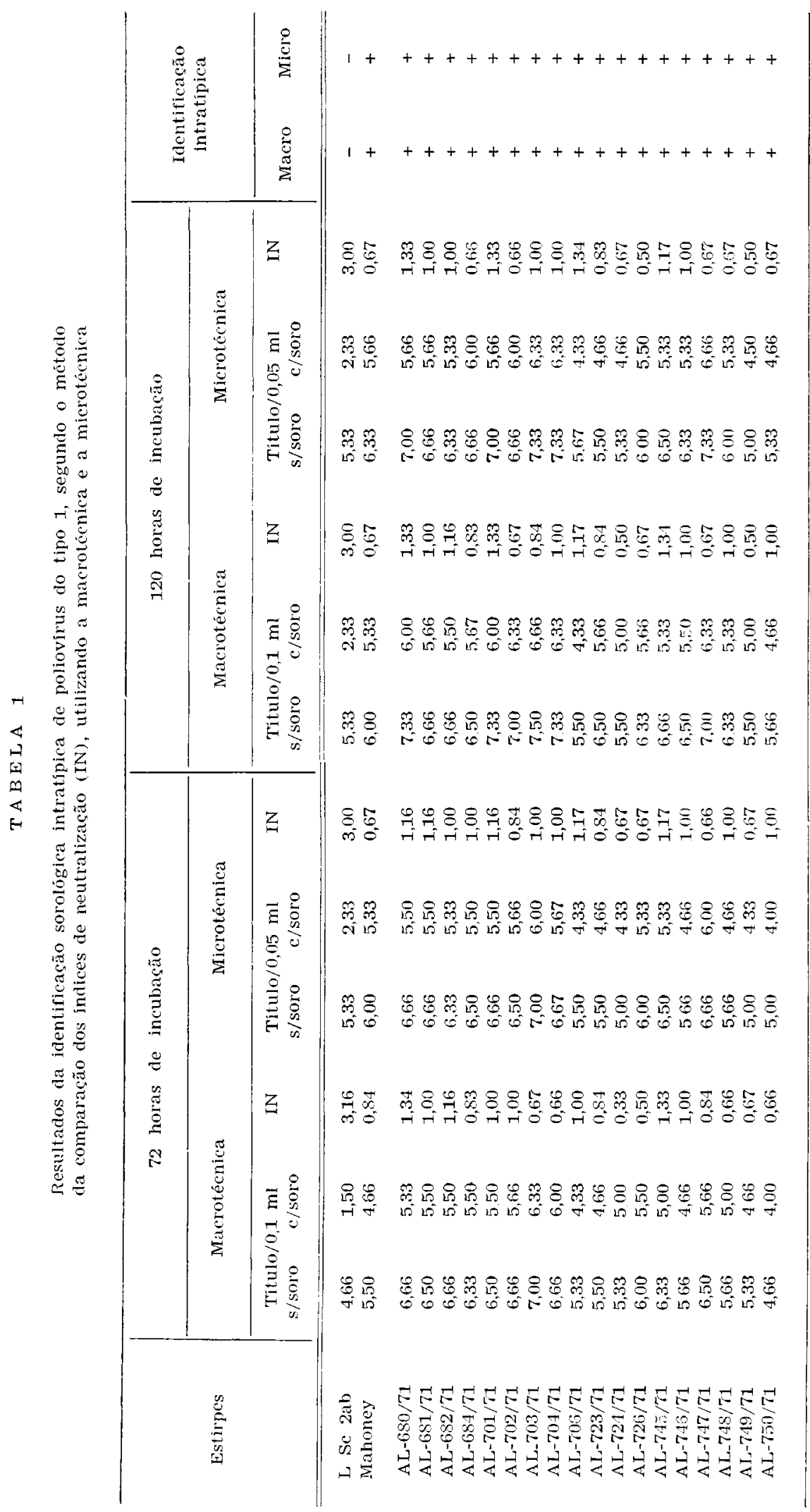




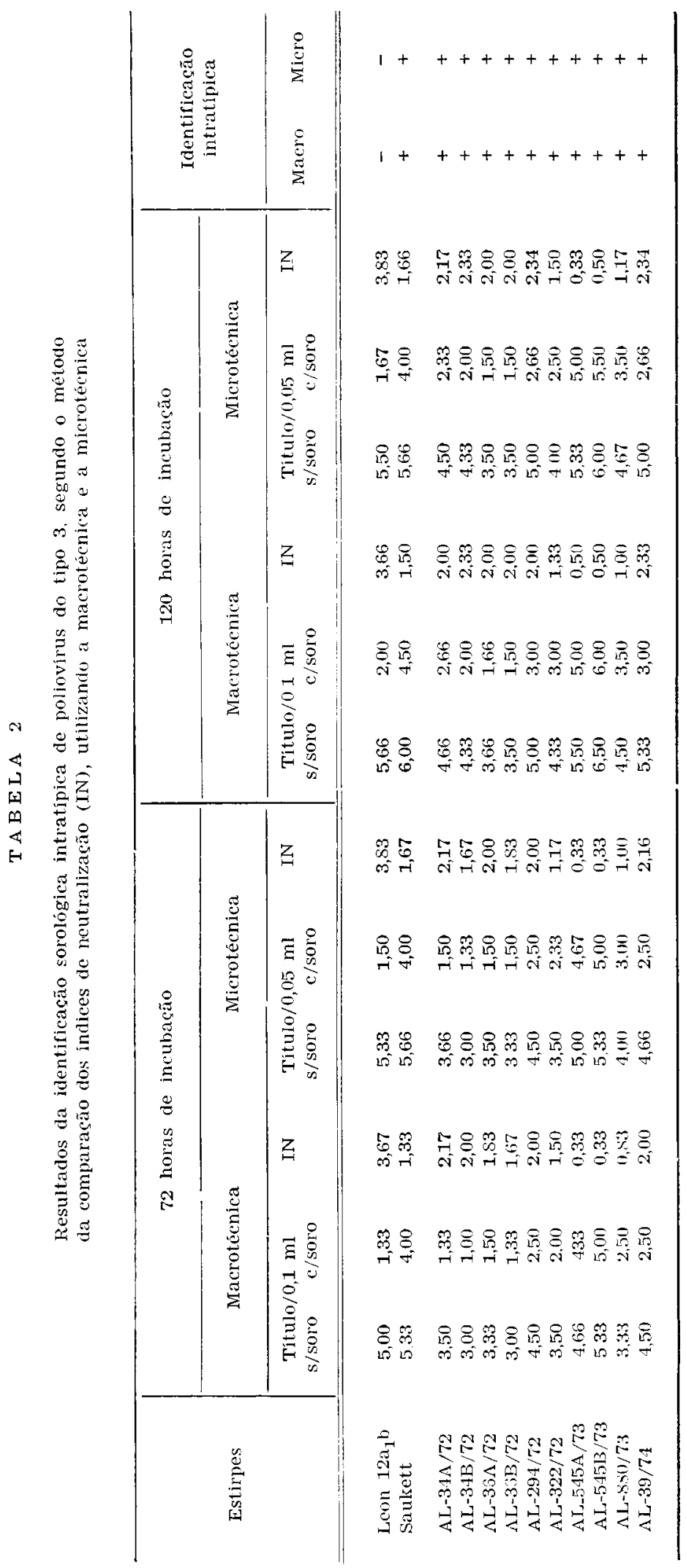


STEWIEN, K. E. \& LACERDA, J. P. G. de - Ltilização da microtécnica para a identificação sorológica intratípica de estirpes de poliovirus dos tipos 1 e 3 . Rev. Saúde públ., S. Paulo, $11: 135-42, \quad 1977$

2. Microtécnica

IN $\geqslant 3.11 \rightarrow$ estirpe isóloga $(-)$;

IN $\leqslant 2,38 \rightarrow$ estirpe heteróloga $(+)$;

$3.11>\mathrm{IA}>2.38 \rightarrow$ intermediária $( \pm)$

Verifica-se assim que todas as 28 estirpes examinadas apresentaram o mesmo resultado de identificação com ambas as técnicas utilizadas. independente do período de incuhação. As 18 estirpes do lipo 1 e as 10 estirpes do tipo 3 foram identificadas como sendo heterólogas às estirpes vacinais LSc2ab e Leon $12 \mathrm{a}_{1} \mathrm{~b}$. Como foi anteriormente descrito. este resultado era esperado, pois todas as estirpes examinadas não apresentaram associação com a vacinação oral de Sabin e procediam de casos paralíticos internados no Hospital de Clínicas da I'niversidade de São Paulo ${ }^{13}$.

A Tabela 3 mostra a concordância entre os índices de neutralização obtidos com a macro e a microtécnica, após 72 horas e 120 horas de incubação. Observa-se que a concordância entre os índices (IN) aumenta com o período de incubação. permanecendo inalterada após períodos maiores do que 120 horas (5 dias). A correlação entre os indices também se mostrou ligeiramente maior com um pe- ríodo de incubação de 120 horas - 0,971 -, do que com um período de 72 horas - 0.931. Consequentemente, a leitura final das provas de identificação intratípica deve ser feita após um período de incubação de 120 horas para se obter uma correspondência maior entre os valores dos indices de neutralização de ambas as técnicas.

Finalmente, a Figura 1 mostra a distribuição dos índices (IN), expressos na forma logarítmica, obtidos com a macro e a microtécnica. Nota-se que os seus valores se distribuem ao longo de uma linha reta com 45 graus de inclinação.

Foi possivel observar no presente estudo de identificação intratípica de poliovírus dos tipos 1 e 3 as seguintes vantagens da microtécnica sobre a macrotécnica:

1. Economia de reagentes. notadamente dos soros hiperimunes anti-Sabin 1 e 3, reduzindo o seu consumo pela metade. Este consumo pode ser reduzido ainda mais. quando se diminui os inóculos das misturas vírussoro de $0.1 \mathrm{ml}$ para $0.05 \mathrm{ml}$ ou mesmo para $0.025 \mathrm{ml}$.

2. Grande economia de células e. conseqüentemente. dos meios de cultivo, da ordem de 10 rezes.

TABELA 3

Concordancia entre os indices de neutralização (IN) obtıdos com a macrotécnica e a microtécnica

\begin{tabular}{|c|c|c|c|c|}
\hline \multirow{2}{*}{$\begin{array}{c}\text { Concordância entre os IN obtidos com } \\
\text { a macrotécnica e a microtécnica }\end{array}$} & \multicolumn{2}{|c|}{72 horas de incubação } & \multicolumn{2}{|c|}{120 horas de incubacão } \\
\hline & $\begin{array}{l}\text { N. }{ }^{\circ} \text { de } \\
\text { estirpes }\end{array}$ & $\begin{array}{c}\text { ró de } \\
\text { concordân- } \\
\text { cia }\end{array}$ & $\begin{array}{l}\text { N. }{ }^{\circ} \text { de } \\
\text { estirpes }\end{array}$ & $\begin{array}{c}\text { \% de } \\
\text { concordân- } \\
\text { cia }\end{array}$ \\
\hline Indices com diferenca de $0,0-0,1 \mathrm{log}$ & 7 & 25,0 & 14 & 50,0 \\
\hline fndices com diferenca de $0,16-0.18 \mathrm{log}$ & 14 & 50,0 & 11 & 39,3 \\
\hline Indices com diferença de $0,33-0,35 \mathrm{log}$ & 7 & 25,0 & 3 & 10,7 \\
\hline Total & 28 & 100,0 & 28 & 100,0 \\
\hline
\end{tabular}


STEWIEN, K. E. \& LACERDA, J. P. G. de -- Utilizaçāo da microtécnica para a identıficação sorológica intratípica de estirpes de poliovirus dos tipos 1 e 3 . Rev. saude públ, S. Paulo. $11: 135.42,1977$.

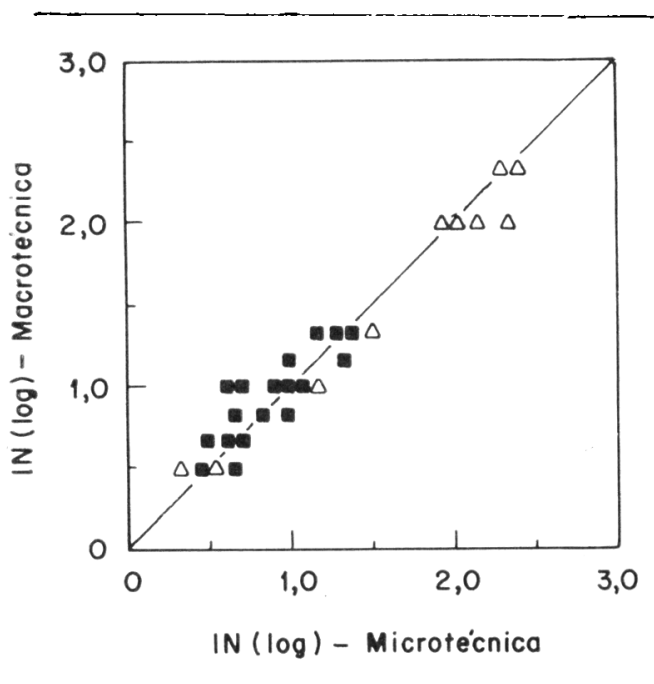

LEGENDA

- Estirpes do tipo 1

$\triangle$ Estirpes do tipo 3

Fıgura - Comparacão entre os indices de neutralızacão (IN) das estirpes de poliovirus dos tipos 1 e 3 , utilizando a macro e micro. técnica.

3. Redução sensível dos esforços humanos e do tempo da execução das provas em mais de 2 vezes. Pela macrotécnica eram necessárias mais de 4 horas para a realização das provas correspondentes à identificação de 10 estirpes de poliovírus. Pela microtécnica. só aproximadamente 2 horas foran necessárias.

4. Redução do tempo de leitura dos resultados em cerca de 5 vezes.

A única destantagem da microtécnica e'm relação à macrotécnica reside nos gastos com a aquisição do equipamento de microtitulação. que entretanto é largamente compensada pelas rantagens mencionadas. além da economia de despesas com a lavagem. desinferção e preparação dos dirersos materiais de laboratório necessários às reaçõos.

\section{CONCLLS I T}

A microtécnica apresentou no presente estudo comparativo a mesma eficiência obtida com a macrotécnica na identificação intratípica de estirpes de poliovírus dos tipos 1 e 3 . Os resultados de identificação encontrados com ambas as técni(as foram totalmente correspondentes $\mathrm{e}$ os índices de neutralização apresentaram correlação elevada. Disto se conclui que a microtécnica pode ser utilizada em substituição da macrotécnica tradicional. com as rantagens acima mencionadas.

STEWIEN, K. E. \& LACERDA. J. P. G. de [The use of the microtechnique for intratypic serodifferentiation of type 1 and 3 poliovirus strains.] Rev. Saúde públ., S. Paulo, 11:135-42, 1977.

ABSTRACTS: The microtechnique was compared to the conventional macrotechniaue for intratypic serodifferentiation of 28 type 1 and 3 poliovirus strains by the method of comparison of neutralization indices. The results of the lests showed a high correlation between the neutralization indices - 0.931 and 0.971 after incubation periods of three and five days. respectively - and all the strains were equally identified by both techniques studied. It is concluded that the microtechnique can be used as an alternative of the macrotechnique for intratypic serodifferentiation of type 1 and 3 polrovirus strains. with the advantage of economy of media and reagents and even with " marked sating in both time and effort.

UNITERMS: Polionirus. Genetic markers. Microtechnque. 
'STEWIEN, K. E. \& LACERDA, J. P. G. de - Utilizaçāo da microtécnica para a identificaçāo sorológica intratípica de estirpes de poliovirus dos tipos 1 e 3. Rev. Saúde públ., S. Paulo, $11: 135$-42, 1977 .

\section{REFERENCIAS BIBLIOGRAFICAS}

1. GWALTNEY, J.N. - Microneutralization test for identification of rhinovirus serotypes. Proc. Soc. exp. Biol. Med., 122:1137-41, 1966.

2. HARRIS, D.J. et aI. - Viruses and disease: II. An Outbreak of parainfluenza type 2 in a children's home. Amer. J. Epidemiol., 87:419-25, 1968.

3 KRIEL R,L. et al. - A microneutralization test for determination of antibodies to rubeola virus. Proc. Soc. exp. Biol. Med., 130:107-9, 1969.

4. MOREAU, P. \& FURESZ, J. - A rapid micro tissue culture assay in BS-C.1 cells for the titration and neutralkation of measles virus. Canad. J. Microbiol.: 13:313-9, 1967.

5. PAULS, F.P. \& DOWDLE, W.R. - A serological study of herpesvirus hominis strains by microneutralization tests. J. Immunol., 98:941-7, 1967.

6. PLOTKIN, S.A. et al. - Intratipic serodifferentiation of polioviruses. Virology, 15:473-85, 1961.

7. ROSEnBAUM, M.J, et al. - A simpli. fied method for virus-tissue culture procedures in microtitration plates. Proc. Soc. exp. Biol. Med., 113:224-9, 1963.

8. SCHMIDT, N.J. et al. - A micro method for performing parainfluenza virus neutralization tests. Proc. Soc. exp. Biol. Med, 122:1062-7, 1966.

9. SCHMIDT, N.J. et al. - Neutralizing, hemagglutination-inhibiting and group complement-fixing antibody responses in human adenovirus infections. $J$. Immunol, 97:64-74, 1966.

10. SEVER, J.I. - Application of a microtechnique to viral serological in. vestigations. J. Immunol., 88:320-9, 1962.

11. SMITH, C.B. et al, - A micro method for assay of neutralizing antibodies against parainfluenza virus type 1 and 3. Proc. Soc exp. Biol. Med., 124:4-7, 1967.

12. STEWIEN, K.E. - Identificacão sorológica intratípica de poliovirus pelo "Método da comparação dos indices de neutralização". Rev. Saúde públ., S. Paulo, 5:243-61, 1971.

13. STEWIEN, K.E, \& LACERDA, J.P.G. de - Aplicação do método da comparaçāo dos indices de neutralização à identificação intratipica de poliovirus dos tipos 1 e 3 , utilizando culturas de células Hep-2. Rev. Saúde públ., S. Paulo, 9:221-8, 1975.

14. STOTT, E.J. \& TYRRELL, D.A.J. Some improved techniques for the study of rhinoviruses using Hela cells. Arch. f. Virusforsch., 23:23644,1968 .

15. SUllivan, E.J.\& ROSENBAUM, M.J. - Methods for preparing tissue culture in disposabie microplates and their use in virology. Amer. J. Epidemiol., 85:424-37, 1967.

16. TAKATSY, G. - The use of spiral loops in serological and virological micro methods. Acta. Microbiol. Acad. Sci. Hung., 3:191-202, 1955.

17. WULFF, $\mathrm{H}$. et al. - A new microneutralization test for antibody determination and typing of parainfluenza and influenza viruses. Proc. Soc. exp. Biol. Med., 125:1045-49, 1967.

Recebido para publicação em 08/09/1975 A provado para publicaço em 10/09/1976 